\title{
Fatal, virus-associated peripheral neuropathy and retinopathy in farmed Penaeus monodon in eastern Australia. II. Outbreak descriptions
}

\author{
R. B. Callinan*, L. Jiang \\ NSW Fisheries, Aquatic Animal Health Unit, Regional Veterinary Laboratory, Wollongbar, \\ New South Wales 2477, Australia
}

\begin{abstract}
Outbreaks of 'peripheral neuropathy and retinopathy' (PNR) occurring during 2 consecutive growout periods (typically October-April) are described for an intensive Penaeus monodon farm in eastern Australia. In the 1998/99 growout period, outbreaks graded minor to severe occurred in 22 of 25 ponds, 12 to 25 wk post-stocking. In the severely affected index pond, harvested 8 wk after outbreak recognition in mid-January, estimated survival for the period late December to harvest was $50 \%$. Minor to moderate losses could be attributed to PNR in the other ponds. Mean survival over the same period for the 14 ponds harvested within 5 wk of outbreak recognition was $93 \%$ (83 to $100 \%$ ); for the 7 ponds harvested 5 to 8 wk after outbreak recognition was $79 \%$ (67 to 92\%) and for the 3 unaffected ponds was $90 \%$ (86 to $95 \%$ ). Analysis indicated a significantly lower risk (Fisher's exact $\mathrm{p}=0.016$ ) of an outbreak in the 2 ponds stocked only with postlarvae from one hatchery (D) versus the 18 ponds stocked only with postlarvae from 3 other hatcheries (A, B and C). In the 1999/2000 growout period, minor to severe PNR outbreaks occurred in all 26 ponds, each stocked with postlarvae from the same hatchery (E), 19 to 21 wk post-stocking. Stocking date in 1999/2000 appeared to influence PNR outbreak severity; for ponds stocked on 2 of the 7 stocking dates versus those stocked on remaining dates, the crude relative risks (CRR) of a severe outbreak, or either a moderate or severe outbreak, were $11.25(1.55<\mathrm{CRR}<81.40)$ and $2.63(1.30<\mathrm{CRR}<5.31)$, respectively. Although inconclusive, study findings are consistent with the hypothesis that 'gill-associated virus' (GAV), the putative causal pathogen identified in a separate pathological study, entered ponds via postlarvae, and that prevalence and/or severity of infection within postlarval batches influenced outbreak severity. The generally high survival in ponds harvested soon after outbreak recognition, together with PNR prevalence of approximately $50 \%$ in prawns collected from 4 ponds 7 wk before those ponds were recognised as affected, also suggest that GAV is highly infectious and that PNR has a relatively long incubation period and/or clinical course.
\end{abstract}

KEY WORDS: Penaeus monodon · Neuropathy $\cdot$ Retinopathy $\cdot$ GAV $\cdot$ PNR $\cdot$ MCMS

\section{INTRODUCTION}

Since 1994, a poorly characterised condition, designated 'mid-crop mortality syndrome' (MCMS) by farmers, has been associated with significant mortalities in Penaeus monodon during the mid to late growout period on many farms in eastern Australia. Investigations of MCMS outbreaks have been hampered by a reported lack of pathognomonic lesions in affected prawns
(Owens et al. 1998), and to date only very brief descriptions of outbreaks consistent with MCMS have been published. Spann et al. (1997) described mortalities, attributed to infection with a rod-shaped virus designated 'gill-associated virus' (GAV), on 4 P. monodon farms in Queensland during 1996. Affected prawns, typically 8 to $15 \mathrm{~g}$ body weight, showed non-specific clinical signs including lethargy, poor appetite, swimming to the edges of ponds and pink to red colouration of appendages and 
body surface. Only minor, non-specific histopathological lesions in lymphoid organ and gills were reported. Owens et al. (1998) reported MCMS outbreaks involving 12 to $15 \mathrm{~g}$ P. monodon on 4 farms in northern Queensland in 1994. Mortality rates reached $80 \%$ in some ponds and there was evidence that 3 of the farms had received postlarvae from the same hatchery. No pathognomonic lesions were found on histopathological examination, but a parvo-like virus, very similar or identical to spawner-isolated mortality virus (SMV; Fraser \& Owens 1996), was demonstrated by electron microscopy in affected prawns and proposed as the causal infectious agent. These authors noted farmers' reports that environmental stressors, such as low dissolved oxygen concentrations or rapid salinity changes, may have had a causal role in MCMS outbreaks.

In this paper, we describe outbreaks, occurring in northern New South Wales (NSW) in the 1998/99 and 1999/2000 growout periods, of a previously unreported disease of farmed Penaeus monodon, designated 'peripheral neuropathy and retinopathy' (PNR). This disease is clinically consistent with MCMS, it is associated with infection by a GAV-like virus, and pathognomonic lesions are consistently present in affected prawns. A description of the pathology of PNR has been published separately (Callinan et al. 2003, this issue).

\section{MATERIALS AND METHODS}

Farm layout and water exchange system. The affected farm, located on the right bank of the
Clarence river estuary, NSW $\left(29^{\circ} 25^{\prime} \mathrm{S}, 153^{\circ} 21^{\prime} \mathrm{E}\right)$, comprised 26 ponds 0.5 to 1.5 ha in surface area. Water was pumped from the adjacent river into 2 reservoirs, each having a separate intake point and pumping system; the larger (Reservoir 1) and the smaller (Reservoir 2) reservoirs supplied Ponds 1 to 21 and Ponds 22 to 26, respectively. An open water exchange system was used and effluent from Ponds 1 to 7 , Pond 8 and Ponds 9 to 26 was discharged to the river via 3 separate outlets (Fig. 1).

Species farmed. Penaeus monodon only was grown during the 1998/99 and 1999/2000 growout periods. However, during the 1997/98 growout period, $P$. japonicus had been grown in Ponds 3, 4, 5 and 16, with $P$. monodon grown in the remaining ponds.

Farm management. The growout period for farmed Penaeus monodon in northern NSW typically extends from October to the following April. Unless otherwise stated, standard production methods for intensively stocked ponds (Chanratchakool et al. 1998) were used during the 1998/99 and 1999/2000 growout periods. Prior to stocking, all ponds were dried out. In most cases, the accumulated central waste was removed and pond bottoms were then lightly tilled. In October of each year, $P$. monodon postlarvae $\left(\mathrm{PL}_{10-15}\right)$ were delivered to the farm from Queensland hatcheries (designated A, B, C, D and E) in polythene bags, each containing approximately 10000 prawns. The postlarvae were acclimated on arrival before being released into ponds. In an attempt to reduce postlarval pathogen loads in some ponds at the 1999/2000 stocking, postlarvae destined for release in 11 of the 26

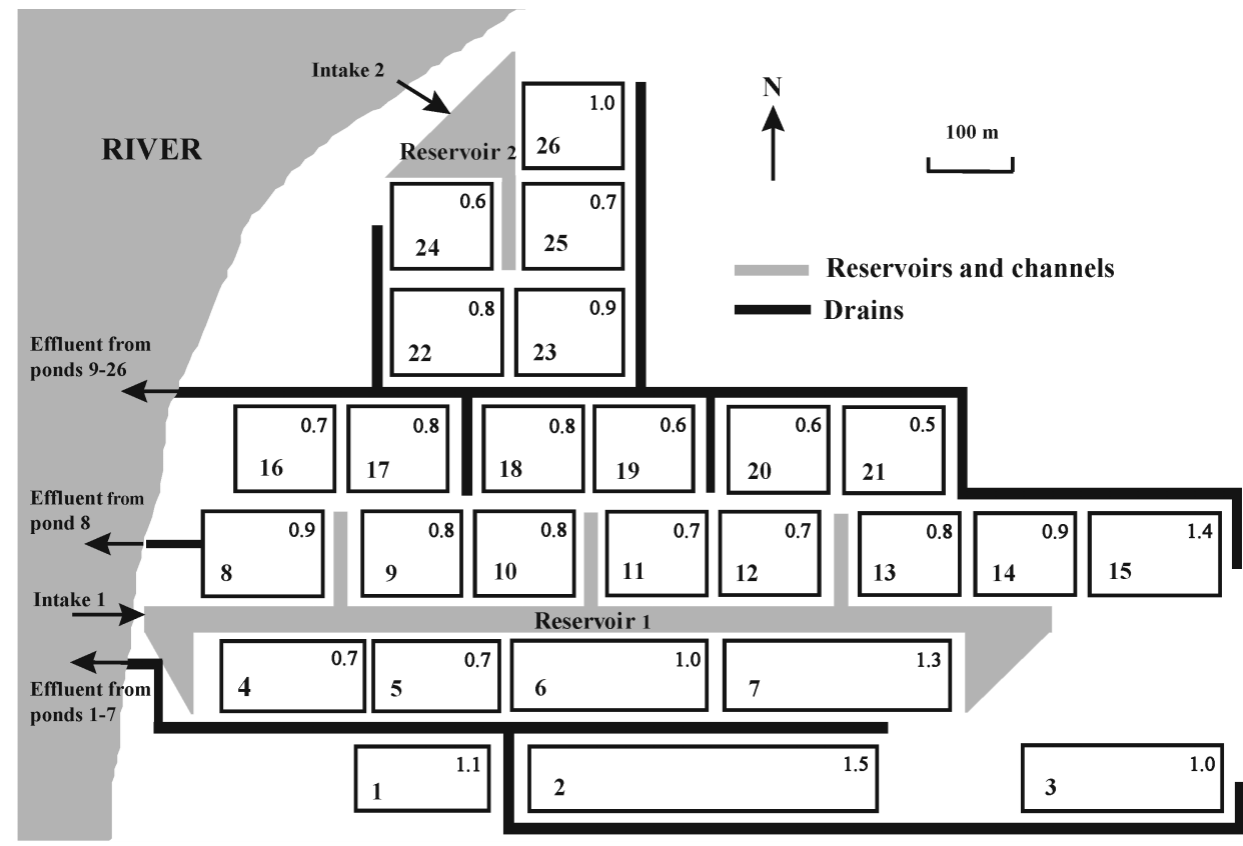

Fig. 1. Farm layout, showing relationships between river, water intake points, reservoirs, ponds, drains and effluent discharge points. For each pond, the pond number is shown in the lower left corner and its surface area (ha) in the upper right corner 
ponds were exposed to $200 \mathrm{ppm}$ formalin for $30 \mathrm{~min}$ and weak postlarvae discarded immediately prior to stocking (Chanratchakool et al. 1998). Post-stocking survival for each pond was estimated in late December and, during the following fortnight, in the 1998/99 growout period only, prawns were transferred between ponds in order to approximately equalise stocking densities. Water in ponds was exchanged as necessary throughout each growout period. Prawns were fed commercial pelleted feed from 2 sources (PT Grobest, Indomakmur, Jakarta, Indonesia, and Aquafeed, Deception Bay, Queensland) 3 or 4 times daily, depending on body weight. Ponds were aerated using paddle wheels and, in some cases, Venturi-type aerators.

Farm records. Farm staff collected the following data for each pond during both growout periods. Appearance and behaviour of prawns was observed daily, and abnormal findings recorded. During the second month post-stocking, mean body weights were estimated weekly or bi-weekly using a convenience sample of prawns collected from feed trays. Subsequently, growth rates were calculated weekly or biweekly from the mean body weight of a sample of 100 prawns collected by cast net. From the second month post-stocking, survival was estimated, initially weekly or bi-weekly but later less frequently, from numbers of prawns present on feed trays (Chanratchakool et al. 1998), as well as from total daily feedconsumption figures, weekly cast-net sample counts and occasional counts by divers. Final survival for each pond was measured at harvest.

Pond environment. The following data were collected from each pond during the 1998/99 growout period. Water column transparency was measured by Secchi disc every morning and afternoon until 14 January and subsequently in the afternoon until 28 February. Dissolved oxygen concentrations, salinity and water temperature for each pond were measured every morning and afternoon from stocking until harvest, except for brief periods in late October and early December, using a TPS 90FL (TPS, Brisbane) waterquality meter; $\mathrm{pH}$ in each pond was also measured using this instrument until 13 February. After each pond had been harvested and drained, the proportion of the pond bottom covered with black sediment was estimated.

Disease diagnosis. During the 1998/99 growout period, the health of prawns in Ponds 8 to 11, 18, and 22 to 26 was regularly monitored as follows. From November to mid-December, 100 prawns were collected weekly from feed trays and examined macroscopically for abnormalities of cuticle, gills, gut, muscle and appendages, as well as abnormal size variations. From mid-December until harvest, 100 prawns were collected weekly by cast net and examined as above, as were representative moribund prawns whenever numbers at pond edges exceeded $10 \mathrm{~d}^{-1}$. Whenever $>10 \%$ of prawns collected from feed trays or by cast net appeared abnormal, major organs from 5 typically affected prawns were fixed with Davidson's fixative and major organs, usually including peripheral nerves and eyes, were processed for histopathological examination using conventional methods (Bell \& Lightner 1988).

Representative moribund prawns were also collected during 1998/99 from selected affected ponds not included in the regular monitoring program and during 1999/2000 from selected affected ponds. These prawns were examined macroscopically and their major organs examined histopathologically as above.

Affected ponds. Ponds were designated 'affected' if at least 10 typically affected, moribund prawns per day were seen daily at the pond edges by farm staff and/or laboratory staff. Clinically affected ponds were designated 'confirmed affected' if a majority of sampled moribund prawns had moderate to severe peripheral neuropathy and/or retinopathy consistent with PNR (Callinan et al. 2003) on histopathological examination. Essential features were mild to severe, focal to diffuse degeneration and necrosis of axons and their sheaths, together with associated glial cell apoptosis in peripheral nerve fibres, and mild to severe, acute to chronic retinitis, associated with degeneration and necrosis of retinular cells and their axons. Outbreak severity in each pond was assessed according to the numbers of moribund or dead prawns consistently seen daily at the pond edges as follows: 10 to 20 prawns ('minor'; +), 20 to 40 prawns ('moderate'; ++ ), $>40$ prawns ('severe'; +++ ).

Terminology and statistical analysis. For this study, 'survival' is defined as the proportion, expressed as a percentage, of prawns alive at the end of a specified period relative to those alive at the beginning of the period. The effects of a number of putative pond-level risk factors for PNR outbreak occurrence were compared between ponds. 'Crude relative risk' (CRR) is defined here as the proportion of affected ponds exposed to the risk factor of interest divided by the proportion of affected ponds not exposed. For example, in the 1998/99 growout period, 3 of 4 affected ponds were stocked only with postlarvae from Hatchery A, while 14 of 16 affected ponds were stocked only with postlarvae from other hatcheries; CRR was therefore 0.86. For each factor the estimate is 'crude' because it is not controlled for the effects of other variables. CRR and chi-square statistics were calculated using the computer program EpiInfo 6.04 (Centres for Disease Control, Atlanta). 


\section{RESULTS}

\section{8/99 growout period}

Initial stocking densities in October ranged from 46 to 74 postlarvae $\mathrm{m}^{-2}$ and survival estimated in late December for each pond ranged from 10 to $66 \%$; the causes of low survivals were not determined. Subsequently, to better balance stocking densities, prawns were transferred between ponds as follows: from Pond 2 to Ponds 4 and 5; from Pond 3 to Pond 9; from Pond 6 to Pond 5; from Pond 13 to Pond 9; from Pond 22 to Pond 18; from Pond 23 to Pond 10; from Pond 25 to Pond 19. Estimated stocking densities for all ponds immediately following these transfers are shown in Table 1. Pond 7 was not stocked.

Minor to severe PNR outbreaks occurred in 22 of the 25 ponds during the mid to latter part of the growout period (Fig. 2). Typically, moribund prawns gathered at the edges of affected ponds. They were often reddish in colour and lethargic, with one or more partially amputated appendage(s), mild to moderate epibiotic fouling, and erosion and melanisation of uropod margins. Generally, numbers of prawns present each day at the edges of affected ponds increased during the first 2 to $3 \mathrm{wk}$ and subsequently remained relatively stable during the outbreak period; where possible, outbreak severity scores for each pond were estimated during this plateau phase. Ponds were harvested between early March and mid-May. Depending on outbreak severity and biomass at risk, ponds were harvested as soon as possible after they were recognised as affected.

From mid-January, farm staff reported large numbers (usually $>40$ ) of moribund prawns, with the clinical signs and gross lesions described above, present

Table 1. Penaeus monodon. 1998/99 growout period. Summarised data relating to postlarval stocking, inter-pond transfers of prawns, 'peripheral neuropathy and retinopathy' (PNR) outbreak occurrence and prawn survival in the 25 stocked ponds. Outbreak severity was ranked according to the numbers of moribund or dead prawns consistently seen daily at the pond edges as follows: 10 to 20 prawns (+), 20 to 40 prawns (++), >40 prawns (+++). na: not affected

\begin{tabular}{|c|c|c|c|c|c|c|c|c|c|}
\hline Pond: & 1 & 2 & 3 & 4 & 5 & 6 & 8 & 9 & 10 \\
\hline Source hatchery for initial stocking & A & A & A & A & A & B & B & B & B \\
\hline Stocking date $(\mathrm{dd} / \mathrm{mm})$ & $27 / 10$ & $26 / 10$ & $28 / 10$ & $28 / 10$ & $27 / 10$ & $23 / 10$ & $7 / 10$ & $7 / 10$ & $12 / 10$ \\
\hline Initial stocking density (no. $\mathrm{m}^{-2}$ ) & 71 & 74 & 71 & 55 & 55 & 58 & 58 & 58 & 53 \\
\hline Survival to time of transfers $(\%)^{a}$ & 25 & 38 & 51 & 22 & 20 & 55 & 34 & 10 & 30 \\
\hline Post-transfer stocking density (no. $\mathrm{m}^{-2}$ ) & 18 & 23 & 29 & 19 & 17 & 29 & 20 & 17 & 17 \\
\hline Stocking-to-affected interval (wk) & 21 & $21^{b}$ & 24 & na & 12 & $12^{\mathrm{b}}$ & $23^{\mathrm{b}}$ & 21 & 24 \\
\hline Severity of outbreak & + & ++ & ++ & na & + & +++ & ++ & + & + \\
\hline Affected-to-harvest interval (wk) & 7 & 7 & 2 & na & 7 & 8 & 2 & 1 & 1 \\
\hline Survival, post-transfers to harvest (\%) & 80 & 84 & 99 & 86 & 75 & 50 & 93 & 88 & 89 \\
\hline Pond: & 11 & 12 & 13 & 14 & 15 & 16 & 17 & 18 & \\
\hline Source hatchery for initial stocking & B & B & B & $\mathrm{C}$ & $\mathrm{C}$ & $\mathrm{C}$ & $\mathrm{C}$ & B & \\
\hline Stocking date (dd/mm) & $12 / 10$ & $15 / 10$ & $15 / 10$ & $12 / 10$ & $12 / 10$ & $6 / 10$ & $6 / 10$ & $12 / 10$ & \\
\hline Initial stocking density (no. $\mathrm{m}^{-2}$ ) & 55 & 58 & 57 & 46 & 49 & 48 & 48 & 53 & \\
\hline Survival to time of transfers $(\%)^{\mathrm{a}}$ & 35 & 41 & 54 & 50 & 51 & 50 & 50 & 40 & \\
\hline Post-transfer stocking density (no. $\mathrm{m}^{-2}$ ) & 19 & 24 & 26 & 23 & 25 & 24 & 24 & 26 & \\
\hline Stocking-to-affected interval (wk) & $18^{\mathrm{b}}$ & 20 & $22^{\mathrm{b}}$ & 23 & $22^{\mathrm{b}}$ & 24 & 24 & 22 & \\
\hline Severity of outbreak & ++ & + & +++ & ++ & ++ & + & + & + & \\
\hline Affected-to-harvest interval (wk) & 7 & 1 & 1 & 7 & 3 & 4 & 2 & 1 & \\
\hline Survival, post-transfers to harvest (\%) & 92 & 100 & 85 & 67 & 83 & 91 & 99 & 96 & \\
\hline Pond: & 19 & 20 & 21 & 22 & 23 & 24 & 25 & 26 & \\
\hline Source hatchery for initial stocking & B & $\mathrm{D}$ & $\mathrm{D}$ & $\mathrm{C}$ & $\mathrm{C}$ & $\mathrm{C}$ & $\mathrm{C}$ & $\mathrm{C}$ & \\
\hline Stocking date $(\mathrm{dd} / \mathrm{mm})$ & $15 / 10$ & $19 / 10$ & $19 / 10$ & $5 / 10$ & $5 / 10$ & $5 / 10$ & $5 / 10$ & $6 / 10$ & \\
\hline Initial stocking density (no. $\mathrm{m}^{-2}$ ) & 57 & 51 & 51 & 49 & 45 & 46 & 47 & 47 & \\
\hline Survival to time of transfers $(\%)^{a}$ & 25 & 39 & 65 & 59 & 60 & 50 & 66 & 60 & \\
\hline Post-transfer stocking density (no. $\mathrm{m}^{-2}$ ) & 20 & 20 & 33 & 25 & 24 & 23 & 26 & 28 & \\
\hline Stocking-to-affected interval (wk) & 23 & na & na & $24^{\mathrm{b}}$ & $19^{\mathrm{b}}$ & $24^{\mathrm{b}}$ & $23^{\mathrm{b}}$ & $24^{\mathrm{b}}$ & \\
\hline Severity of outbreak & + & na & na & + & + & + & + & ++ & \\
\hline Affected-to-harvest interval (wk) & 1 & na & na & 3 & 8 & 5 & 3 & 6 & \\
\hline Survival, post-transfers to harvest (\%) & 96 & 89 & 95 & 99 & 88 & 88 & 97 & 67 & \\
\hline
\end{tabular}




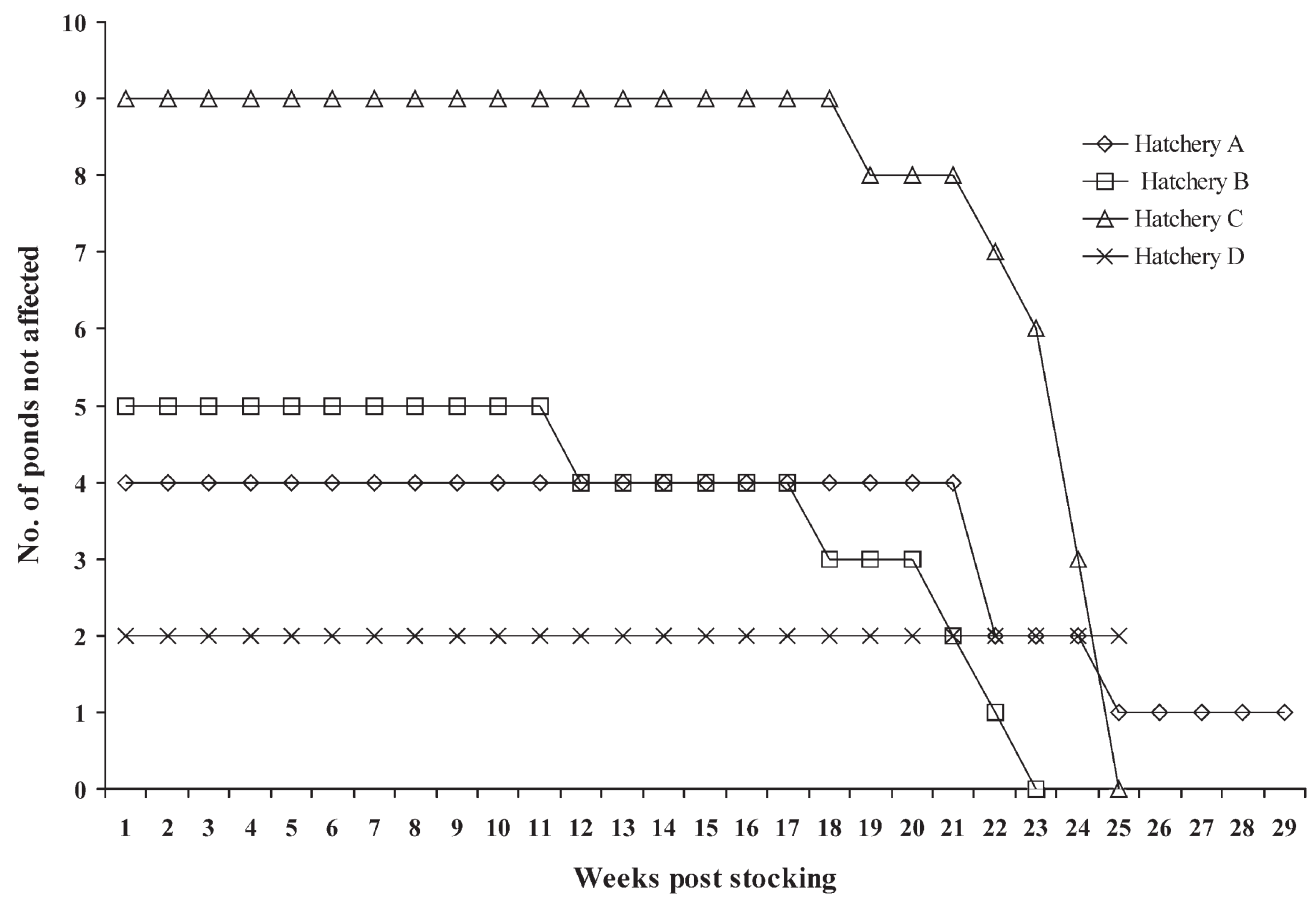

Fig. 2. Occurrence of 'peripheral neuropathy and retinopathy' (PNR)-affected ponds in relation to hatchery of origin and weeks post-stocking during the 1998/99 growout period. The 5 ponds which held Penaeus monodon prawns derived from more than one hatchery are not included

daily at the edges of Pond 6, i.e. not one of the 10 ponds regularly monitored by laboratory staff. Moderate to severe PNR lesions were present on histopathological examination in 25/25 moribund prawns collected from the pond edge during February and March; full descriptions of these lesions are presented in a separate paper (Callinan et al. 2003).

Between mid-January and the completion of harvesting in late May, similarly affected moribund prawns were seen daily at the edges of all remaining ponds except Ponds 4, 20 and 21. Moderate to severe PNR lesions were confirmed histopathologically in 47/48 typically affected moribund prawns collected from 10 of these ponds during this period (Table 1).

Mild to severe lesions consistent with PNR were also seen on histopathological examination of $2 / 5$ prawns, with clinical abnormalities apparently unrelated to PNR, collected on 12 January 1999 from Pond 9, and of 5/12, 6/10 and 2/4 similarly affected prawns collected on 1 February 1999 from Ponds 24, 25 and 26, respectively.

\section{Pond environment}

Generally, water quality remained within acceptable limits (Chanratchakool et al. 1998) during the growout period, although short-term fluctuations of some variables outside these limits occurred in most ponds. However, similar fluctuations occurred in both affected and unaffected ponds and appeared temporally unrelated to recognition of a pond as affected.

\section{9/2000 growout period}

Between mid- and late October, 26 ponds were stocked with postlarvae from Hatchery E only. Stocking densities ranged from 48 to 53 postlarvae $\mathrm{m}^{-2}$ and prawns were not subsequently transferred between ponds. Minor to severe PNR outbreaks, clinically and pathologically consistent with those of 1998/99, were recognised in all ponds in early to mid-March. Data relating to stocking dates, pre-stocking formalin exposure, PNR outbreak severity and survival at harvest are summarised in Table 2 .

Using these data, crude relative risk statistics for a number of putative pond-level risk factors for PNR outbreak occurrence were calculated for the 1998/99 (Table 3) and 1999/2000 (Table 4) growout periods.

Using Fisher's exact test, differences in PNR outbreak occurrence in 1998/99 in the 2 ponds stocked with postlarvae from Hatchery D alone, versus the 18 
Table 2. Penaeus monodon. 1999/2000 growout period. Summarised data relating to postlarval stocking, formalin treatments, 'peripheral neuropathy and retinopathy' (PNR) outbreak occurrence and prawn survival in the 26 stocked ponds. Outbreak severity was ranked according to the numbers of moribund or dead prawns consistently seen daily at the pond edges as follows: 10 to 20 prawns $(+), 20$ to 40 prawns $(++),>40$ prawns $(+++)$. Y: yes; N: no

\begin{tabular}{|c|c|c|c|c|c|c|c|c|c|}
\hline Pond: & 1 & 2 & 3 & 4 & 5 & 6 & 7 & 8 & 9 \\
\hline Stocking date $(\mathrm{dd} / \mathrm{mm})$ & $25 / 10$ & $26 / 10$ & $26 / 10$ & $26 / 10$ & $27 / 10$ & $27 / 10$ & $27 / 10$ & $21 / 10$ & $21 / 10$ \\
\hline Pre-stocking formalin exposure & $\mathrm{N}$ & $\mathrm{Y}$ & $\mathrm{N}$ & $\mathrm{Y}$ & $\mathrm{N}$ & $\mathrm{N}$ & $\mathrm{N}$ & $\mathrm{Y}$ & $\mathrm{N}$ \\
\hline Severity of outbreak ${ }^{\mathrm{a}}$ & + & +++ & +++ & ++ & + & + & +++ & + & ++ \\
\hline Survival, stocking to harvest $(\%)^{\mathrm{b}}$ & 60 & 63 & 57 & 60 & 70 & 61 & 57 & 77 & 86 \\
\hline Pond: & 10 & 11 & 12 & 13 & 14 & 15 & 16 & 17 & 18 \\
\hline Stocking date $(\mathrm{dd} / \mathrm{mm})$ & $20 / 10$ & $20 / 10$ & $19 / 10$ & $19 / 10$ & $19 / 10$ & $19 / 10$ & $21 / 10$ & $21 / 10$ & $21 / 10$ \\
\hline Pre-stocking formalin exposure & $\mathrm{N}$ & $\mathrm{Y}$ & $\mathrm{N}$ & $\mathrm{Y}$ & $\mathrm{Y}$ & $\mathrm{N}$ & $\mathrm{N}$ & $\mathrm{Y}$ & $\mathrm{N}$ \\
\hline Severity of outbreak ${ }^{\mathrm{a}}$ & +++ & +++ & + & ++ & + & + & ++ & + & + \\
\hline Survival, stocking to harvest $(\%)^{b}$ & 50 & 62 & 102 & 78 & 115 & 140 & 72 & 83 & 82 \\
\hline Pond: & 19 & 20 & 21 & 22 & 23 & 24 & 25 & 26 & \\
\hline Stocking date $(\mathrm{dd} / \mathrm{mm})$ & $20 / 10$ & $20 / 10$ & $20 / 10$ & $25 / 10$ & $25 / 10$ & $22 / 10$ & $22 / 10$ & $25 / 10$ & \\
\hline Pre-stocking formalin exposure & $\mathrm{N}$ & $\mathrm{Y}$ & $\mathrm{N}$ & $\mathrm{N}$ & $\mathrm{Y}$ & $\mathrm{Y}$ & $\mathrm{N}$ & $\mathrm{Y}$ & \\
\hline Severity of outbreak ${ }^{\mathrm{a}}$ & ++ & + & +++ & ++ & + & + & ++ & + & \\
\hline Survival, stocking to harvest $(\%)^{\mathrm{b}}$ & 106 & 85 & 79 & 40 & 47 & 47 & 46 & 56 & \\
\hline
\end{tabular}

ponds stocked from Hatchery A, B or C alone, were examined; Fisher's exact 2-tailed test, $\mathrm{p}=0.016$.

\section{DISCUSSION}

In a separate study, Callinan et al. (2003) described the pathology of PNR in prawns from the 1998/99 pond outbreaks and proposed GAV as the probable causal infectious agent. The current, largely descriptive study of the 1998/99 and 1999/2000 outbreaks is hypothesisforming in nature. It enables an initial examination of important epidemiological issues, including the putative causal role of GAV, possible source(s) of such infection, and its methods of spread on farms, as well as the role of pond-level environmental factors in outbreak causation.

Any epidemiological study of PNR must consider events at the hatchery as well as in ponds. Although no definitive studies have been reported, it is possible that GAV infection spreads by several routes in eastern Australian hatcheries, where individual rearing tanks are usually stocked with fertilised ova from 3 to 4 spawners.

Walker et al. (2001) reported GAV infection in $97 \%$ (144/148) of wild-caught Penaeus monodon broodstock from several north Queensland sites which serve as primary broodstock sources for eastern Australian hatcheries. Moreover, $100 \%$ (50/50) of postlarvae and $98 \%(55 / 56)$ of juveniles from hatcheries and ponds in southeast Queensland were also shown to be infected. These findings raise the possibility of vertical transmission of GAV from females and/or males, as well as horizontal transmission within hatchery tanks and between them via aerosols or contaminated equipment. Typically in Australian hatcheries, 250000 to 500000 postlarvae (i.e. a 'batch') survive in each tank at the end of a production cycle, at which time they are placed into bags in lots of approximately 10000 prior to shipment to farms. In practice, because of in-transit handling methods, pond sizes and stocking densities, ponds on the study farm are often stocked with postlarvae derived exclusively or predominantly from a single batch. However, postlarvae from more than one batch are necessarily stocked into some, usually larger, ponds. The potential exists, therefore, for considerable between-pond variation in the total load of a pathogen, such as GAV, which may be carried by any stocked batch.

The pattern of spread of an infectious disease within a population depends on a number of factors, including the incubation period of the disease, the infectivity of the agent, the proportion of susceptible animals in the population and the stocking density (Thrusfield 1995). In prawn ponds, moribund, infected animals are typically cannibalised by healthy pond-mates, which may thereby become infected themselves, depending on the mode of transmission of the infection and the agent's infectivity. So long as the proportion of uninfected or subclinically infected prawns in a pond remains high rela- 
tive to moribund prawns, the latter will generally be cannibalised before they can gather at pond edges in numbers sufficient for the pond to be recognised as affected.

Although inconclusive, the following key study findings can be interpreted in the above context and provide a basis for further investigations of PNR epidemiology.

Findings suggested a significant difference (Fisher's exact test, $\mathrm{p}=0.016$ ) in outbreak occurrence in 1998/99 between the 2 ponds stocked from Hatchery $\mathrm{D}$ only, versus the 18 ponds stocked from Hatcheries A, B or C only. Because of the small numbers of ponds involved, these data could not be examined for confounding associated with factors such as pond location, pre-stocking pond preparation or date of stocking. For the 8 ponds stocked on 20 and 26 October 1999 versus the 18 ponds stocked on the other 5 stocking days $(19,21,22,25$ and 27 October 1999) in 1999/2000, the crude relative risk of a severe outbreak, or either a moderate or severe outbreak, was 11.25 (1.55 $<\mathrm{CRR}<81.40)$ and $2.63(1.30<\mathrm{CRR}<5.31)$, respectively. However, there were no clear relationships between pond stocking dates and outbreak severity in the 1998/99 growout period. The estimated post-transfer survival for the 1998/99 index pond (Pond 6), harvested 8 wk after becoming affected, was $50 \%$. Mean posttransfer survival for the other 24 ponds in 1998/99 were as follows: $93 \%$ (83 to $100 \%$ ) for the 14 ponds harvested within 5 wk of becoming affected, $79 \%$ (67 to 92\%) for the 7 ponds harvested more than 5 wk after becoming affected and $90 \%$ (86 to $95 \%$ ) for the 3 unaffected ponds. Approximately $50 \%$ of prawns (15/31), with clinical abnormalities apparently unrelated to PNR, collected in 1998/99 from 4 ponds 7 wk before they were recognised as affected, had mild to severe PNR lesions on histopathological examination.

Data relating to a number of pond-level risk factors for outbreak occurrence, other than those discussed above, were examined. Within the limitations of these data, none appeared significant.

Clearly, the occurrence of PNR outbreaks in all but 3 of 51 ponds over the 2 growout periods, the biased selection for risk factor analysis of 1999/2000 stocking dates, and the limited number of prawns examined in 1998/99 before source ponds were recognised as affected, renders any conclusions based on the study findings as no more than tentative at this stage. Despite these limitations, however, the results of the stocking-date risk factor analysis, together with findings of a pathological study of PNR (Callinan et al. 2003) strongly implicating GAV as the causal infectious agent, combined with other evidence of vertical transmission of GAV (Walker et al. 2001), suggest the virus entered the farm via infected postlarval batches and that the prevalence and/or severity of batch infection influenced the severity of PNR outbreaks in ponds. A possible association between pond outbreaks and

Table 4. Penaeus monodon. Crude relative risk (CRR) statistics for putative pond-level risk factors for 'peripheral neuropathy and retinopathy' (PNR) outbreaks in the 1999/2000 growout period. Dates given as dd/mm/yy

\begin{tabular}{|lcc|}
\hline Putative pond-level risk factor & $\begin{array}{c}\text { CRR of severe outbreak } \\
(95 \% \text { confidence limits })\end{array}$ & $\begin{array}{c}\text { CRR of moderate or severe } \\
\text { outbreak }(95 \% \text { confidence limits })\end{array}$ \\
\hline $\begin{array}{l}\text { Stocked on either 20/10/99 or 26/10/99 } \\
\text { No pre-stocking formalin exposure }\end{array}$ & $11.25(1.55<\mathrm{CRR}<81.40)$ & $2.63(1.30<\mathrm{CRR}<5.31)$ \\
& $1.47(0.32<\mathrm{CRR}<6.63)$ & $1.65(0.68<\mathrm{CRR}<3.99)$ \\
\hline
\end{tabular}


hatchery of origin, also noted for MCMS by Owens et al. (1998), is not surprising given the high prevalence of GAV infection in broodstock and the apparent opportunities for vertical and horizontal infection transmission in hatcheries. Comparisons of survival in ponds in 1998/99 indicated that relatively few PNRaffected prawns died or were cannibalised prior to outbreak recognition in a pond, and that losses could be minimised by harvesting ponds within the following 5 wk. These low mortality rates, together with PNR prevalence of approximately $50 \%$ in 4 ponds $7 \mathrm{wk}$ before outbreaks were recognised, suggest that GAV is highly infectious in the hatchery and/or the pond environment, and that PNR has a relatively long incubation and/or clinical course. The relatively early expression of PNR in Pond 6 in 1998/99 may have been due to higher viral load in stocked postlarvae and/or higher viral strain pathogenicity and virulence in that pond.

The finding that approximately $50 \%$ of prawns from 4 ponds had PNR lesions $7 \mathrm{wk}$ before the ponds were recognised as affected meant that the time of outbreak commencement in any pond could not be identified with certainty. Hence relationships, if any, between pond-level environmental stressors, such as low dissolved oxygen concentrations or rapid salinity changes (Owens et al. 1998), and outbreak initiation could not be determined. Owens (1997) suggested that birds feeding on infected prawns were the most likely cause of an on-farm spread of MCMS. If PNR is a component disease within MCMS (Callinan et al. 2003), the current study findings did not support this suggestion; outbreaks in 1998/99 were no more common in ponds within $300 \mathrm{~m}$ of the index pond (Pond 6) than in more distant ponds. There was no evidence that exposure to formalin and removal of weak postlarvae immediately prior to stocking was effective in reducing subsequent PNR outbreak severity in ponds.

In zoogeographic terms, the wild Penaeus monodon populations, which serve as broodstock sources for eastern Australian hatcheries, inhabit the northeastern, tropical Australia sub-region and are restricted from mixing with other populations in adjacent subregions by oceanic barriers (Dall et al. 1990). It is reasonable to assume that these populations carry distinct viruses and other microflora, some of which, like GAV,

Editorial responsibility: Chris Baldock, South Brisbane, Queensland, Australia will emerge as pathogens in aquaculture (Owens 1997). It is therefore essential that Australian farmers and prawn health scientists work together closely to develop timely, cost-effective control and prevention measures for significant emerging diseases such as PNR.

Acknowledgements. This study was funded in part by the Australian Centre for International Agricultural Research (FIS/97/125). We thank management and staff at the study farm for their enthusiastic cooperation. We also thank Chris Baldock, Ian Anderson, David Jordan, Leigh Owens and Paul Smith for helpful discussions and advice.

\section{LITERATURE CITED}

Bell TA, Lightner DV (1988) A handbook of normal penaeid shrimp histology. World Aquaculture Society, Baton Rouge, FL

Callinan RB, Jiang L, Smith PT, Soowannayan C (2003) Fatal, virus-associated peripheral neuropathy and retinopathy in farmed Penaeus monodon in eastern Australia. I. Pathology. Dis Aquat Org 53:181-193

Chanratchakool P, Turnbull J, Funge-Smith SJ, MacRae IH, Limsuwan C (1998) Health management in shrimp ponds, 3rd edn. Aquatic Animal Health Research Institute, Bangkok

Dall W, Hill BJ, Rothlisberg PC, Staples DJ (1990) The biology of the Penaeidae. In: Blaxter JHS, Southward AJ (eds) Advances in marine biology, Vol 27, Academic Press, London, p 1-489

Fraser CA, Owens L (1996) Spawner-isolated mortality virus from Australian Penaeus monodon. Dis Aquat Org 27: 141-148

Owens L (1997) Special topic review: the history of the emergence of viruses in Australian prawn aquaculture. World J Microbiol Biotechnol 13:427-431

Owens L, Haqshenas G, McElnea C, Coelen R (1998) Putative spawner-isolated mortality virus associated with mid-crop mortality syndrome in farmed Penaeus monodon from northern Australia. Dis Aquat Org 34:177-185

Spann KM, Cowley JA, Walker PJ, Lester RJG (1997) A yellow-head-like virus from Penaeus monodon cultured in Australia. Dis Aquat Org 31:169-179

Thrusfield M (1995) Veterinary epidemiology, 2nd edn. Blackwell Scientific Publications, Oxford

Walker PJ, Cowley JA, Spann KM, Hodgson RA, Hall MR, Withyachumnarnkul B (2001) Yellow head complex viruses: transmission cycles and typo-geographical distribution in the Asia-Pacific region. In: Browdy CL, Jory DE (eds) The new wave. Proc Spec Sess Sustainable Shrimp Culture. The World Aquaculture Society, Baton Rouge, FL, p 292-302

Submitted: October 19, 2001; Accepted: June 29, 2002 Proofs received from author(s): February 7, 2003 